\title{
Mdm2-SNP309 polymorphism in prostate cancer: no evidence for association with increased risk or histopathological tumour characteristics
}

\author{
R Stoehr ${ }^{*, 1}$, F Hitzenbichler², B Kneitz ${ }^{3}$, CG Hammerschmied', M Burger ${ }^{4}$, A Tannapfel ${ }^{5}$ and A Hartmann' \\ 'Institute of Pathology, University Hospital Erlangen, Universitaetsstrasse 22, Erlangen 91 054, Germany; ${ }^{2}$ Institute of Pathology, University of Regensburg, \\ Franz-Josef-Strauss-Allee 11, Regensburg 93053, Germany; ${ }^{3}$ Department of Urology, University of Wuerzburg, Oberduerrbacherstrasse 6, Wuerzburg \\ 97080, Germany; ${ }^{4}$ Department of Urology, University of Regensburg, Franz-Josef-Strauss-Allee II, Regensburg 93053, Germany; Institute of Pathology, \\ Ruhr-University of Bochum, Buerkle de la Camp -Platz I, Bochum 44789, Germany
}

The search for inherited cancer susceptibility factors is a major focus of epidemiologic cancer studies. Analyses of single-nucleotide polymorphisms (SNP) in a variety of genes revealed a correlation between a specific allele variant and cancer predisposition. Human mouse double-minute 2 protein (Mdm2) is a cellular E3 ligase capable of ubiquitination and degradation of p53. Therefore, Mdm2 is a crucial factor of cell cycle control and cell survival. The Mdm2 promoter SNP309 was shown to increase Mdm2 expression and can, thereby, inhibit the 553 pathway. This SNP was found to be associated with increased risk and early onset of various malignancies. For prostate cancer no studies are reported to date. In a case-control study we determined the distribution of the Mdm2 SNP309 in I 45 male subjects with prostate cancer and in 124 male controls without any malignancy using RFLP analysis. Cases and controls showed a similar distribution of the SNP $(P=0.299)$. Genotype distribution showed neither an association with histopathological characteristics of the tumours nor with prognosis. Age at disease onset was also not modified by the SNP. This first study of the Mdm2 SNP309 in prostate cancer patients suggests no correlation between a certain allelic variant and an increased cancer risk. British Journal of Cancer (2008) 99, 78-82. doi: I 0.I038/sj.bjc.660444I www.bjcancer.com

Published online 24 June 2008

(c) 2008 Cancer Research UK

Keywords: prostate cancer; Mdm2 SNP309; RFLP; p53 pathway

Genomic integrity and the ability of accurate repair of cellular damage are crucial prerequisites for controlled proliferation and differentiation. These processes are highly regulated and disruption of components of this network favours malignant transformation.

The p53 protein is one of the most important coordinators of cellular response to genotoxic stress (Levine 1997). The tumour suppression functions of p53 are widespread and mediated by various mechanisms. p53 is tightly regulated and the exact mechanisms of p53 activation are still not fully understood (Brooks and $\mathrm{Gu}, 2006$ ). Several studies have shown that the major mechanism of p53 control is its degradation by the ubiquitinproteasome pathway (Brooks and $\mathrm{Gu}, 2006$ ). Human mouse double-minute 2 protein $(\mathrm{Mdm} 2)$ (gene locus on chromosome 12q14.3-q15) is a cellular E3 ligase able to ubiquinate and degrade p53 (Haupt et al, 1997). As a key negative regulator of p53, overexpression of $\mathrm{Mdm} 2$ is associated with accelerated tumour progression and lack of response to therapy in various human malignancies (Bond et al, 2004). Besides gene amplification, a naturally occurring single-nucleotide polymorphism (SNP) in the promoter of the Mdm2 gene (SNP309, T $>$ G) was found that increases mRNA and protein levels (Bond et al, 2004). Several

*Correspondence: Dr R Stoehr;

E-mail: robert.stoehr@uk-erlangen.de

Revised 21 April 2008; accepted 21 April 2008; published online 24 June 2008 studies have analysed the impact of the Mdm2 SNP309 on cancer risk in sporadic and hereditary malignancies and a recently published meta-analysis revealed that there is only little effect on the risk of common cancers from this SNP alone. Nevertheless, a modification of the onset of tumour formation and the individual prognosis might be influenced by this sequence variation (Wilkening et al, 2007). Interestingly, Bond and co-workers found an acceleration of tumour formation in a gender-specific and hormone-dependent manner by this polymorphism (Bond et al, 2006).

Prostate cancer ( $\mathrm{PCa}$ ) poses one of the major health care problems today. PCa is responsible for approximately $11 \%$ of all male cancers in Europe, and about $9 \%$ of all cancer deaths in men are caused by this malignancy within the European Union, the course of this malignancy is unpredictable and therapy not warranted in all patients (Heidenreich et al, 2008). A variety of treatment options ranging from watchful waiting to radical surgery underlines the necessity for the identification of reliable factors permitting individual risk assessment.

Major progress in discovery of SNPs has lead to a rapid increase of genetic association studies in various malignancies including $\mathrm{PCa}$. Despite promising results no specific PCa-related genes have been established yet. However, the involvement of variants in androgen pathway genes in PCa aetiology could recently be confirmed reproducibly (Lindström et al, 2006).

Alterations in the p53 pathway are already described in $\mathrm{PCa}$ including Mdm2 protein overexpression in about $30-45 \%$ of the 
analysed tumours. This overexpression was associated with advanced tumour stage, higher tumour volume and increased cell proliferation (Osman et al, 1999; Leite et al, 2001; Khor et al, 2005). Although these data indicate a potential role of $\mathrm{Mdm} 2$ overexpression in $\mathrm{PCa}$, there have been no studies published investigating the distribution of the functional Mdm2 SNP309 in PCa patients to date. Therefore, the aim of the presented study was the analysis of the allele frequencies of the Mdm2 SNP309 in patients with PCa compared to a healthy control group to assess a possible influence of this promoter alteration on cancer risk, histopathological tumour characteristics and prognosis.

\section{MATERIALS AND METHODS}

\section{Samples}

Overall, 145 patients with PCa were included in our study. All PCa patients underwent a radical prostatectomy. Formalin-fixed and paraffin-embedded tissue samples from these patients were available from prior transurethral resection (TUR-P, $n=31$ ) or from the prostatectomy specimens $(n=114)$. For comparison 124 samples from a male control group of patients without any malignancy acquired at the Department of Urology, University of Regensburg was investigated.

All tumours were diagnosed according to the 2004 WHO classification of prostate tumours (Epstein et al, 2004) and staged according the TNM system (Sobin and Wittekind, 2002). Characteristics of the study participants are shown in Table 1. Detailed clinical information was available from $65 \mathrm{PCa}$ patients. Clinical follow-up (mean 71 months and range 6-144 months) revealed that 20 tumours showed a recurrence within 3 years (defined as detectable serum prostate specific antigen (PSA) following radical prostatectomy $\left(>0.2 \mathrm{ng} \mathrm{ml}^{-1}\right)$, whereas 45 tumours did not recur within at least 5 years. Prior IRB approval was obtained for the study.

\section{Tissue microdissection and DNA isolation}

DNA was extracted from normal prostate tissue or peripheral blood using the High Pure PCR Template Preparation Kit (Roche $\mathrm{GmbH}$, Mannheim, Germany) according to the manufacturer's instructions.

\section{Mdm2 SNP309 analysis}

Single-nucleotide polymorphism analysis was carried out by restriction fragment length polymorphism analysis (RFLP) of the promoter region which contains an Msp A1I site (5'-CMGCKG-3') in presence of the G-allele (Sotomaa et al, 2005). The presence of the G-allele resulted in a digest of the PCR product $(157 / 106+51 \mathrm{bp})$, PCR products containing the T-allele remained unaffected.

\section{Amplification of promoter region variants and RFLP analysis}

Single-nucleotide polymorphism region was amplified by PCR using primers (5-FAM-sense: 5'-CGCGGGAGTTCAGGGTAAAG-3'; antisense: $5^{\prime}$-CTGAGTCAACCTGCCCACTG- $3^{\prime}$ ) obtained from Metabion (Martinsried, Germany) in a total volume of $25 \mu \mathrm{l}$ containing approximately $100 \mathrm{ng}$ DNA, $0.2 \mathrm{~mm}$ dNTP (Roche Diagnostics), $0.18 \mu \mathrm{M}$ primers and $0.0025 \mathrm{U}_{\mu} \mathrm{l}^{-1}$ GoTaq (Promega, Mannheim, Germany). The thermal cycling conditions were as follows: initial denaturation for $3 \mathrm{~min}$ at $95^{\circ} \mathrm{C}, 35$ cycles of denaturation at $95^{\circ} \mathrm{C}$ for $1 \mathrm{~min}$, annealing at $61^{\circ} \mathrm{C}$ for $1 \mathrm{~min}$, elongation at $72^{\circ} \mathrm{C}$ for $1 \mathrm{~min}$ and final primer extension at $72^{\circ} \mathrm{C}$ for $10 \mathrm{~min}$.

PCR products were incubated overnight with $5 \mathrm{U} M s p$ A1I (New England Biolabs, Frankfurt/Main, Germany) and $100 \mu \mathrm{g} \mathrm{ml}^{-1} \mathrm{BSA}$ at $37^{\circ} \mathrm{C}$ in a total volume of $30 \mu \mathrm{l}$ to ensure complete digestion. Restriction fragments were separated by capillary electrophoresis using an ABI PRISM 310 genetic analyser (Applied Biosystems, Foster City, CA) and analysed with the GeneScan Analysis Software. Representative examples of genotyping are shown in Figure 1. Ten randomly selected cases were also sequenced to verify the RFLP results. In all cases identical results were obtained (data not shown).

\section{Statistical analysis}

To test if the genotype distribution followed Hardy-Weinberg equilibrium, the public software at http://ihg.gsf.de/cgi-bin/hw/ hwal.pl was used. $\chi^{2}$ statistics (two-sided Fisher's exact test) were used to evaluate case-control differences in the distribution of genotypes and to analyse associations between genotypes and clinical or histopathological characteristics. $P<0.05$ was interpreted as statistically significant.

\section{RESULTS}

All analysed samples gave interpretable results. The genotype distribution in our cohorts followed the Hardy-Weinberg equilibrium in cases $(P=1.000)$ and controls $(P=0.578)$. Genotype distribution between cases and controls did not differ significantly. Although there was a higher frequency of $\mathrm{T} / \mathrm{T}$ genotypes in prostate cancer patients this difference did not reach statistical significance $(P=0.299$, Table 2 , Figure 2$)$. There was also

Table I Characteristics of study participants

\begin{tabular}{|c|c|c|c|c|}
\hline & Cases & & Controls & \\
\hline Number: & $n=145$ & & $n=124$ & \\
\hline Age: & $\begin{array}{l}\text { Median: } 65 \\
\text { Mean: } 64.2( \pm 6.0)\end{array}$ & Range: $46-74$ & $\begin{array}{l}\text { Median: } 69 \\
\text { Mean: } 68.5( \pm 9.9)\end{array}$ & Range: $40-88$ \\
\hline Stage: & $\begin{array}{l}\text { pTI-3a } \\
\text { pT3b-3c } \\
\text { No data available }\end{array}$ & $\begin{array}{l}n=105 \\
n=28 \\
n=12\end{array}$ & & \\
\hline Gleason score: & Median: 7 & Range: $3-10$ & & \\
\hline Gleason sum: & $\begin{array}{l}3-4 \\
5-7 \\
8-10 \\
\text { No data available }\end{array}$ & $\begin{array}{l}n=3 \\
n=103 \\
n=27 \\
n=12\end{array}$ & & \\
\hline Recurrence: & $\begin{array}{l}\text { Recurrence within } 3 \text { years } \\
\text { No recurrence within } 5 \text { years } \\
\text { No data available }\end{array}$ & $\begin{array}{l}n=20 \\
n=45 \\
n=80\end{array}$ & & \\
\hline
\end{tabular}




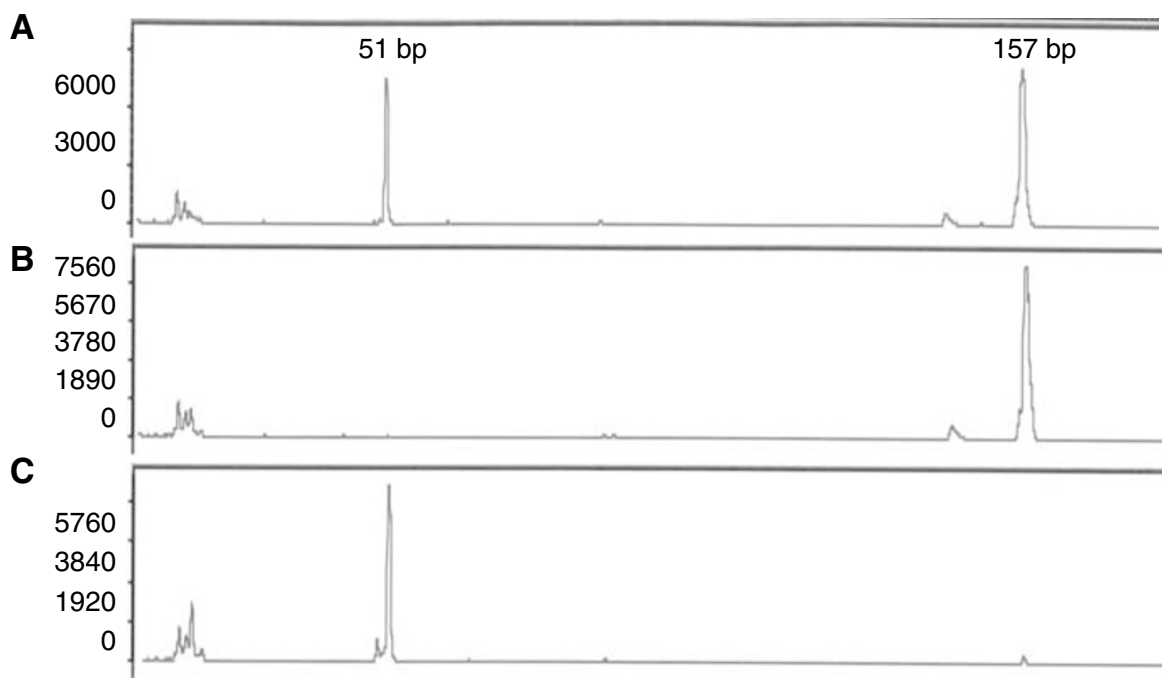

Figure I Representative examples for RFLP analyses. (A) T/G genotype resulting in an undigested I57 bp product and a digested 5 I bp product. The second fragment from the Msp All digest (I06 bp) is not visible due to $5^{\prime}$-FAM-labelling of the PCR product. (B) T/T genotype showing only the I57 bp PCR product after Msp All digest. (C) G/G genotype displays only the 5 I bp after digest of the PCR product.

Table 2 Distribution of allelic variants between participants

\begin{tabular}{lccll}
\hline Genotype & Cases (\%) & Controls (\%) & Comparison & \\
\hline$T T$ & $61(42.1)$ & $41(33.1)$ & & \\
GT & $66(45.5)$ & $64(51.6)$ & $P=0.299$ & OR: 0.680 \\
GG & $18(12.4)$ & $19(15.3)$ & $P=0.131$ & $95 \%$ Cl: $0.413-1.120$ \\
$T T$ & $61(42.1)$ & $41(33.1)$ & & \\
TG+GG & $84(57.9)$ & $83(66.9)$ & & \\
\hline
\end{tabular}

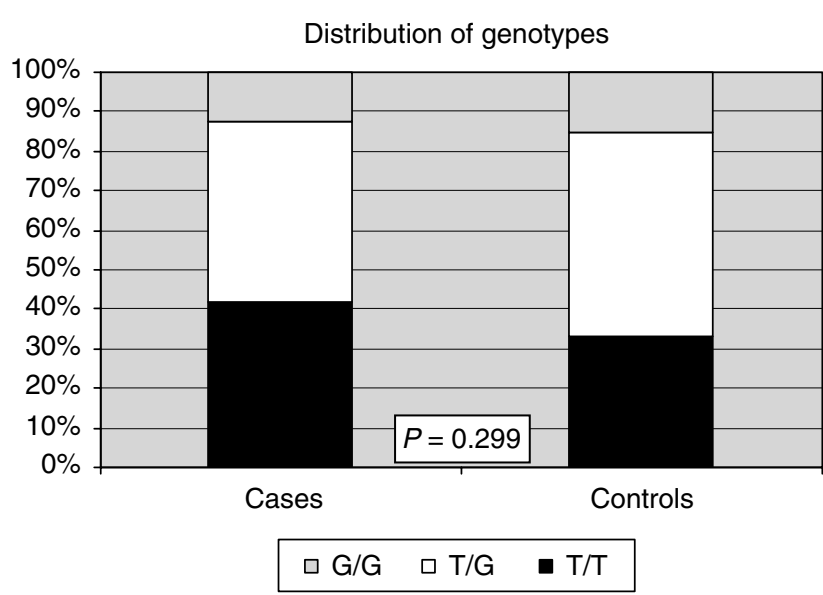

Figure 2 Graphical illustration of the genotype distribution in cases and controls.

no association between overall disease risk and presence of the polymorphic promoter variant (T/T vs $\mathrm{T} / \mathrm{G}+\mathrm{G} / \mathrm{G} ; \quad P=0.131$, Table 2). In addition, we also did not observe any significant correlation of genotypes and disease recurrence or Gleason score (Table 3). As the Mdm2 SNP309 was previously shown to be related with disease onset at younger age also in sporadic tumours (eg, bladder cancer (Sanchez-Carbayo et al, 2007)) we tested our cases towards this hypothesis. Within our cohort there was no significant association between genotypes and early disease onset ( $\leqslant 60$ years $v s>60$ years, Table 3 ).

\section{DISCUSSION}

The Mdm2 SNP309 is a plausible cancer predisposing allele due to the crucial role of $\mathrm{Mdm} 2$ in the cellular p53 pathway. The T to $\mathrm{G}$ variant was shown to result in increased Mdm2 synthesis and was found to be correlated with the risk of cancer or an early onset of tumour formation at various organ sites ( $\mathrm{Hu}$ et al, 2007). In this study, we genotyped 145 cases of PCa and 124 male controls for this polymorphism. In our cohort, we did not find any association of the SNP309 with tumour risk, age at tumour onset, histopathological characteristics of the tumours or prognosis.

Overexpression of $\mathrm{Mdm} 2$ and its clinical consequences were already described in PCa (Osman et al, 1999; Leite et al, 2001; Khor et $a l, 2005)$ but the molecular basis of this upregulation is still unclear. As our study revealed no significant changes in the allelic distribution between PCa patients and men without any malignancy, it is unlikely that the Mdm2 SNP309 plays an important role for increased Mdm2 expression in prostate tumours. Moreover, chromosomal deletions at $12 \mathrm{q}$ have not been described in PCa to date, making a preferential loss of the $\mathrm{Mdm} 2 \mathrm{~T}$-allele resulting in a $\mathrm{Mdm} 2$ overexpression during PCa development unlikely (Dumur et al, 2003).

Mdm2 overexpression could be linked to gene amplification in several malignancies (eg, malignant melanoma, non-small cell lung cancer and lipomatous tumours (Dworakowska et al, 2004; Nilsson et al, 2004; Muthusamy et al, 2006) but in PCa a specific Mdm2 gene amplification could not be demonstrated by Southern blot analysis so far (Ittmann et al, 1994). Interestingly, frequent gains of chromosome 12q including the regions $12 \mathrm{q} 13-\mathrm{q} 14$ that are in close proximity to the $\mathrm{Mdm} 2$ gene locus have been reported in various studies using comparative genomic hybridisation (Sattler et al, 1999; Zitzelsberger et al, 2001) but to date no gene copy number 
Table 3 Distribution of allelic variants between relevant tumour/patient characteristics

\begin{tabular}{|c|c|c|c|c|c|}
\hline Genotype & Cases with recurrence (\%) & Cases without recurrence (\%) & Comparison & & \\
\hline $\begin{array}{l}T T \\
G T \\
G G \\
T T \\
T G+G G\end{array}$ & Gleason sum $<7$ (\%) & Gleason sum $\geqslant 7(\%)$ & & & \\
\hline & Age $\leqslant 60(\%)$ & Age $>60(\%)$ & & & \\
\hline
\end{tabular}

$\mathrm{Cl}=$ confidence interval; $\mathrm{OR}=$ odds ratio.

analysis specific for $\mathrm{Mdm} 2$ using highly sensitive, fluorescencebased methods has been performed.

The G-variant of the Mdm2 promoter polymorphism increases the affinity of transcription factors for example, Sp1. As long as Mdm2 gene amplification is not analysed in detail in PCa, overexpression of $\mathrm{Sp} 1$ might be speculated as an activator of increased Mdm2 synthesis. Numerous studies have documented that Sp1 activity and/or Sp1 expression levels are elevated in various human cancers and are associated with prognosis (Safe and Abdelrahim, 2005; Deniaud et al, 2006). In PCa elevated Sp1 levels have not been described so far but an increased expression of Sp2 in PCa cells was found recently (Phan et al, 2004) indicating a possible role of deregulation of $\mathrm{Sp} / \mathrm{KLF}$ family member expression in $\mathrm{PCa}$.

Mdm2 is still discussed as a promising target for a therapeutical approach (Vassilev, 2007). The identification of the first selective and potent inhibitors of the $\mathrm{p} 53-\mathrm{Mdm} 2$ interaction emphasised the usage of small-molecule inhibitors as viable alternative to chemotherapy for selective p53 activation in tumours with wild-

\section{REFERENCES}

Bond GL, Hirshfield KM, Kirchhoff T, Alexe G, Bond EE, Robins H, Bartel F, Taubert H, Wuerl P, Hait W, Toppmeyer D, Offit K, Levine AJ (2006) MDM2 SNP309 accelerates tumor formation in a gender-specific and hormone-dependent manner. Cancer Res 66: $5104-5110$

Bond GL, Hu W, Bond EE, Robins H, Lutzker SG, Arva NC, Bargonetti J, Bartel F, Taubert H, Wuerl P, Onel K, Yip L, Hwang SJ, Strong LC, Lozano G, Levine AJ (2004) A single nucleotide polymorphism in the MDM2 promoter attenuates the p53 tumor suppressor pathway and accelerates tumor formation in humans. Cell 119: $591-602$

Brooks CL, Gu W (2006) p53 ubiquitination: Mdm2 and beyond. Mol Cell 21: $307-315$

Deniaud E, Baguet J, Mathieu AL, Pages G, Marvel J, Leverrier Y (2006) Overexpression of $\mathrm{Sp} 1$ transcription factor induces apoptosis. Oncogene 25: $7096-7105$

Dong JT (2006) Prevalent mutations in prostate cancer. J Cell Biochem 97: $433-447$

Dumur CI, Dechsukhum C, Ware JE, Cofiled SS, Best AM, Wilkinson DS, Garrett CT, Ferreira-Gonzalez A (2003) Genome-wide detection of LOH in prostate cancer using human SNP microarray technology. Genomics 81: $260-269$ type p53. In PCa p53 alterations are a rare event in primary tumours and associated with more aggressive disease, metastasis and transition from androgen-dependent to androgen-independent growth (Dong, 2006). Therefore, a subset of prostate tumours with Mdm2 overexpression might evolve as a suitable target for the application of selective $\mathrm{Mdm} 2$ inhibitors in the future.

In conclusion, our case-control study suggests that the Mdm2 promoter polymorphism SNP309 has no influence on PCa risk or prognosis, and relevant inherited alterations in PCa-related genes remain to be uncovered.

\section{ACKNOWLEDGEMENTS}

We thank Sigrun Ammon and Nina Niessl for excellent technical assistance.

\section{Conflict of interest}

The authors state no conflict of interest.
Dworakowska D, Jassem E, Jassem J, Peters B, Dziadziuszko R, Zylicz M, Jakobkiewicz-Banecka J, Kobierska-Gulida G, Szymanowska A, Skokowski J, Roessner A, Schneider-Stock R (2004) MDM2 gene amplification: a new independent factor of adverse prognosis in nonsmall cell lung cancer (NSCLC). Lung Cancer 43: 285-295

Epstein JI, Algaba F, Allsbrook WC, Bastacky S, Boccon-Gibod L, De Marzo AM, Egevad L, Furusato M, Hamper UM, Helpap B, Humphrey PA, Iczkowski KA, Lopez-Beltran A, Montironi R, Rubin MA, Sakr WA, Samaratunga H, Parkin DM (2004) Tumours of the prostate. In Pathology and Genetics. Tumours of the Urinary System and Male Genital Organs, Eble JN, Sauter G, Epstein JI, Sesterhenn IA (eds) World Health Organization, classification of tumours. pp 159-216. IARC, Lyon

Haupt Y, Maya R, Kazaz A, Oren M (1997) Mdm2 promotes the rapid degradation of p53. Nature 387: 296-299

Heidenreich A, Aus G, Bolla M, Joniau S, Matveev VB, Schmid HP, Zattoni F (2008) EAU guidelines for prostate cancer. Eur Urol 53: $68-80$

Hu Z, Jin G, Wang L, Chen F, Wang X, Shen H (2007) MDM2 promoter polymorphism SNP309 contributes to tumor susceptibility: evidence from 21 case-control studies. Cancer Epidemiol Biomarkers Prev 16: $2717-2723$ 
Ittmann M, Wieczorek R, Heller P, Dave A, Provet J, Krolewski J (1994) Alterations in the p53 and MDM-2 gene are infrequent in clinically localized, stage B prostate adenocarcinomas. Am J Pathol 145: 287-293

Khor LY, Desilvio M, Al-Saleem T, Hammond ME, Grignon DJ, Sause W, Pilepich M, Okunieff P, Sandler H, Pollack A (2005) MDM2 as a predictor of prostate carcinoma outcome: an analysis of radiation therapy oncology group protocol8610. Cancer 104: $962-967$

Leite KR, Franco MF, Srougi M, Nesrallah LJ, Nesrallah A, Bevilacqua RG, Darini E, Carvalho CM, Meirelles MI, Santana I, Camara-Lopes LH (2001) Abnormal expression of MDM2 in prostate carcinoma. Mod Pathol 14: $428-436$

Levine AJ (1997) p53, the cellular gatekeeper for growth and division. Cell 88: $323-331$

Lindström S, Zheng SL, Wiklund F, Jonsson BA, Adami HO, Bälter KA, Brookes AJ, Sun J, Chang BL, Liu W, Li G, Isaacs WB, Adolfsson J, Grönberg H, Xu J (2006) Systematic replication study of reported genetic associations in prostate cancer: strong support for genetic variation in the androgen pathway. Prostate 66: 1729-1743

Muthusamy V, Hobbs C, Nolgueira C, Cordon-Cardo C, McKee PH, Chin L, Bosenberg MW (2006) Amplification of CDK4 and MDM2 in malignant melanoma. Genes Chromosomes Cancer 45: 447-454

Nilsson M, Meza-Zepeda LA, Mertens F, Forus A, Myklebost O, Mandahl N (2004) Amplification of chromosome 1 sequences in lipomatous tumors and other sarcomas. Int J Cancer 109: 363-369

Osman I, Drobnjak M, Fazzari M, Ferrara J, Scher HI, Cordon-Cardo C (1999) Inactivation of the p53 pathway in prostate cancer: impact on tumor progression. Clin Cancer Res 5: 2082-2088
Phan D, Cheng CJ, Galfione M, Vakar-Lopez F, Tunstead J, Thompson NE, Burgess RR, Najjar SM, Yu-Lee LY, Lin SHL (2004) Identification of Sp2 as a transcriptional repressor of carcinoembryonic antigen-related cell adhesion molecule 1 in tumorigenesis. Cancer Res 64: 3072-3078

Safe S, Abdelrahim M (2005) Sp transcription factor family and its role in cancer. Eur J Cancer 41: 2438-2448

Sanchez-Carbayo M, Socci ND, Kirchoff T, Erill N, Offit K, Bochner BH, Cordon-Cardo C (2007) A polymorphism in HDM2 (SNP309) associated with early onset in superficial tumors, TP53 mutations, and poor outcome in invasive bladder cancer. Clin Cancer Res 13: 3215-3220

Sattler HP, Rohde V, Bonkhoff H, Zwergel T, Wullich B (1999) Comparative genomic hybridization reveals DNA copy number gains to frequently occur in human prostate cancer. Prostate 39: 79-86

Sobin LH, Wittekind C (2002) TNM Classification of Malignant Tumors. Wiley \& Sons, New York

Sotomaa K, Liyanarachchi S, Mecklin JP, Järvinen H, Aaltonen LA, Peltimäki P, de la Chapelle A (2005) p53 codon 72 and Mdm2 SNP309 polymorphisms and age of colorectal cancer onset in Lynch syndrome. Clin Cancer Res 11: 6840-6844

Vassilev LT (2007) MDM2 inhibitors for cancer therapy. Trends Mol Med 13: $23-31$

Wilkening S, Bermejo JL, Hemminki K (2007) MDM2 SNP 309 and cancer risk: a combined analysis. Carcinogenesis 28: 2262-2267

Zitzelsberger H, Engert D, Walch A, Kulka U, Aubele M, Höfler H, Bauchinger M, Werner M (2001) Chromosomal changes during development and progression of prostate adenocarcinomas. Br J Cancer 84: $202-208$ 